\title{
$S$ sciendo
}

\section{Relationship between Selection, Optimization and Compensation and the Work Ability of Nurses over Fifty Years of Age}

\author{
Tanja ŽMAUC ${ }^{1}$, Danica ŽELEZNIK ${ }^{1,2}$ and Oto TEŽAK ${ }^{3}$ \\ ${ }^{1}$ Alma Mater Europaea - ECM, Maribor, Slovenia, tanja.zmauc@gmail.com \\ ${ }^{2}$ Faculty of Health and Social Sciences, Slovenj Gradec, Slovenia, zeleznik.danica@gmail.com \\ ${ }^{3}$ University of Maribor, Faculty of Electrical Engineering and Computer Science, Slovenia, oto.tezak@um.si
}

\begin{abstract}
Background and purpose: The raising of the retirement age in the field of nursing care increases the need for successful aging strategies in the work environment. The purpose of this paper is to analyse the application of selection, optimization and compensation and their correlation with the working ability of nurses aged fifty and over in Slovenia.

Design/Methodology/Approach: The study encompasses 433 nurses over the age of $50(\mathrm{M}=53.75 \pm 2.40$ years) working in 13 hospitals across Slovenia. Two measurement instruments used in the field of nursing were adapted, the model of Selection, Optimization and Compensation (SOC) and the Work Ability Index (WAI). Data was processed using descriptive statistical methodology. The correlation between statistical variables was calculated using Spearman's correlation coefficients. For a description of the functional relationship between SOC use and calendar age, linear and potential regression functions were used.

Results: We found out that the use of SOC is slightly growing with the calendar age of the nurses. The most used SOC element is "selection". Calculated WAI for nurses is at the lower end of the classification category "good" (M = $36.98 \pm 6.46)$ There is a positive correlation between SOC and WAI ( $r s=0.23)$, causality was not studied.

Conclusions: Increased use of SOC can lead to better work ability by nurses over fifty. Therefore, in the future, nurses will need to be trained and motivated to use SOC strategies.
\end{abstract}

Keywords: Nursing; work ability index; selection, optimization and compensation; successful aging.

\section{Introduction}

Society ages and the population of the elderly continues to grow. Also, the retirement age is growing. The motivation for our study was to support hospital nursing management by ensuring work ability and successful aging of nurses over 50 years of age.

Models of successful aging are gaining in popularity. One of the main challenges of an aging society is to maintain quality of life, despite the inevitable changes that occur in the lives of older people (Tovel and Carmel 2014, $255)$. Western countries respond to an increased proportion of elderly in their population by raising retirement ages. As a result, the proportion of older employees will continue to increase across all professions.

In nursing, the long-term trend towards a shortfall of nursing care providers has been apparent for a long time, for which reason the profession is unable to serve all the needs of the population (WHO, 2017). The reasons for the lack of nursing staff are more and remain, inter alia, a consequence of the lack of young people choosing this profession, the exodus of professionals due to better working conditions and earnings elsewhere, as well as migration and retirement (WHO, 2017). Healthcare is an area charac-

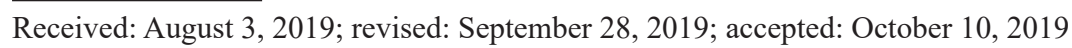


terized by an unfavorable working environment and conditions, such as psychosocial stress, shift work and manual load management (Sandeva and Koleva, 2016, 750).

Many authors point to the need for the implementation of strategies that aim to maintain nurses in working environments for as long as possible. Such is achievable through the provision of working environments in which an individual can work easily, qualitatively and professionally until retirement age, or even longer (Long and Griffiths, 2013, 20; Rozman and Tominc, 2014, 9; Maurits et al., 2015, 9)

One of such tools is the original selection, optimization and compensation (hereafter SOC) model introduced by Baltes and Baltes (1990). It was especially adapted and tested for nurses as the "SOC-in-nursing-scale" by (Müller et al., 2013), and it is the first known research of the association between SOC in nursing and the work ability of nurses.

The "SOC-in-nursing-scale" tool developed by (Müller et al., 2013) is interesting to the Slovenian environment as well, as there are no similar tools. The instrument is short, contains nine items, three for each category (selection, optimization and compensation), and it is easy to use. In combination with the Work Ability Index (hereafter WAI), it can give a complex picture of the state of the work environment. That is why we have decided to use "SOC-in-nursing-scale" in the hospital nursing environment in Slovenia.

The purpose of this study is to research nurses aged fifty and over in Slovenian hospitals. According to our knowledge, the research of this group has not been covered in academic journals. In this paper we focus on three main topics: application of the adapted SOC model from Müller et al. (2013), calculation of the WAI, and finally study of the correlation between SOC and the WAI for nurses over fifty years of age. The following three research questions specify the aim of the paper:

- Are there differences in the mean value of SOC results between our research and the research of Müller et al. (2013)?

- Which element of the SOC is most commonly used by nurses fifty and over in Slovenia?

- Is SOC use by nurses fifty and over in Slovenia dependent on calendar age?

- Does SOC use by nurses fifty and over in Slovenia correlate with WAI assessment?

\section{Literature Review}

\subsection{Definition of successful aging}

Gerontologists have long agreed that aging does not occur on a specific date or at a certain age, the birth of the first grandchild, or in accordance with the statutory criteria for retirement (Nimrod and Ben-Shem, 2015, 814). As with age itself, successful aging does not have a single definition. One of the first definitions of successful aging is "adding life to the years" in the final period of human existence, with Havighurst $(1961,8)$ contemplating that contented individuals are those who enjoy life and are happy with it. Rowe and Kahn $(1997,433)$ define successful aging using three elements: low probability of illness and disease-related disability, high cognitive and physical functional ability, together with active involvement in life, with the greatest emphasis on the latter. Britton et al. $(2008,1102)$ assigned the factors of successful aging into four groups: socioeconomic situation, early life factors, healthy lifestyle and psychosocial factors. They found that the socioeconomic situation in middle age had a major impact on entry into old age without major diseases and with good functional ability. Lee et al. $(2011,210)$ developed four factor models of successful aging, consisting of physical, psychological and social support, together with leisure activities. The absence of chronic disease, functional independence and satisfaction with life were the main components of the model of successful aging, Gureje et al. (2014, 836). Martin et al. $(2015,163)$ noted that flexibility, social support and spirituality/religiosity are of great help in the successful aging of individuals and their families. Lin et al. $(2016,1)$ believe that one of the factors for achieving successful aging is maintaining a high level of physical fitness. Otherwise, Lin et al. $(2016,4)$ associate successful aging with complete independence in daily activities, the absence of cognitive impairment and symptoms of depression, together with satisfactory social activities.

Many seniors report successful aging, regardless of objective health status. Tkatch et al. $(2017,485)$ thus find that in this context of successful aging, the individual's perception of health is important, is not just the number of illnesses they are afflicted with. Parish et al. $(2019,23)$ find that culture, knowledge, and stereotypes about aging influence perceptions of aging. Adults choose individual priorities that subconsciously determine which aspects of aging are under control. When they perceive that they can control an individual aspect of aging, and when it is important to them, they adjust their behavior to achieve the goal. Conversely, when they believe that the aging aspect cannot be controlled or is irrelevant to them, they seek to accept that fact.

Research shows that some factors for successful aging 
can be influenced by an individual's behavior. The main objective of Bosnes et al. $(2019,1)$ was to investigate the impact of middle-aged factors on successful aging beyond 20 years, and they found that middle-aged lifestyle (smoking, physical activity, alcohol consumption, obesity and social support) influences successful ageing. Non-smoking and good social support were the strongest predictors of successful aging in their research. Gopinath et al. $(2018,1)$ examined the temporal association between physical activity and successful aging. Higher levels of physical activity have been found to have an impact on successful aging, as they increase the likelihood of surviving an additional 10 years without chronic illness, cognitive and functional impairment.

Most of these definitions of successful aging refer to those individuals who are no longer in employment. The basic variables of successful aging in the workplace, which were studied by Cheung and Wu $(2012,449)$, were flexibility and health, a positive attitude, personal safety, as well as career growth with goal orientation. Of course, a strategy for successful aging is also an option. This has been specifically adapted for healthcare providers by Müller et al. (2013) and is based on the model of Selection, Optimization and Compensation of Baltes and Baltes (1990). The SOC model allows individuals to control their goals despite - or even because - of impairments and increased vulnerabilities (Baltes and Carstensen 1996, 405).

\subsection{Selection, Optimization and Compensation (SOC)}

Baltes $(1997,371)$ speaks of selection, optimization and compensation as the basis of a development theory that is not unique to the elderly, but at the same time is inextricably linked to every developmental process.

Baltes and Carstensen (1996) describe the selection as active or passive, internal or external, planned or automatic. In aging, selection pertains to the consequences of increasing life restrictions or to the expectations of certain personal and environmental changes, which are often less relevant in old age. Selection thus allows an individual to circumvent a specific field entirely or simply to limit tasks and objectives within a particular area. It can be proactive or reactive. It may include a change of environment (relocation), active behavioral changes (reduction in the number of obligations) or passive adaptation (avoiding certain activities, leaving others accountable). Proactivity means that the current operation is monitored, and thus, in due course, the anticipated changes and potential future losses are adequately prepared for. A reactive selection is one that is unpredictable, and only sudden changes to the individual enforce such a choice. According to Baltes and Carstensen (1996), optimization refers to the enrichment and increase of resources, and thus to improving functionality and flexibility in selected areas of life. Optimization can appear in existing areas or involve investments in new areas and objectives. Baltes and Carstensen (1996) also provide an explanation of a third option represented by restitution and the choice to maintain existing objectives through the application of new assets used to compensate for deficiencies, thus preserving the pre-existing state through optimizing the new one.

The application of the SOC model is also of interest in the nursing environment, as evidenced by several studies (Müller et al., 2012; Müller et al., 2013; Weigl et al., 2013; von Bonsdorff et al., 2014; Müller et al., 2015; Baethge et al., 2016; Moghimi et al., 2017). Weigl et al. (2013) investigated direct and interactive effects of age in health care workers $(n=173)$, job control, and the use of SOC strategies in predicting work ability. They found out that a negative relationship between age and work ability was weakest for employees with high job control and high use of SOC strategies. The research of Weigl et al. (2013) suggests that the use of successful aging strategies and enhanced control at work are conducive to maintaining the work ability of aging employees. Their findings indicate that job control is positively correlated with work ability. Results of the meta-analysis by Moghimi et al. (2017) show that SOC strategy use is positively related to age, job autonomy, self-reported job performance, non-self-reported job performance, job satisfaction, and job engagement, whereas SOC strategy use is not significantly related to job tenure, job demands, and job strain. The study by Weber et al. (2019) examines the relationship between leucocyte telomere length (LTL), a potential biomarker for biological aging, and SOC and learning opportunities as strategies involving efficient management and resource gain at work. In a cross-sectional study, 141 blood samples were collected from experts in geriatric care for LTL measurement with a quantitative real-time polymerase reaction. Likewise, all participants were asked, with standardized questionnaires, to evaluate their learning opportunities at work and use of SOC strategies. Weber et al. (2019) find that a mismatch between SOC and learning opportunities can negatively impact successful aging.

Research by Müller et al. $(2012,5137)$ is based on the findings of other studies, namely that the working ability of nurses decreases with age. In a study involving nurses ( $n=438$, on average 38.5 years old), among others, an SOC model was applied for optimization in relation to the support of work-related ability.

The relationship between SOC, organizational equity, age and working ability of employees $(\mathrm{n}=605$, on average 43.7 years old) was studied by von Bonsdorff et al. (2014, 326) at University Hospital in Finland. In a survey of nursing care providers $(\mathrm{n}=136)$ at German hospitals, Baethge et al. (2016), ascertained whether selective optimization with compensation is appropriate for individual health care professionals who wish to maintain their performance under a high workload. Müller et al. (2015) conducted a controlled trial with the help of nursing providers $(\mathrm{n}=$ 
70), by way of which they attempted to influence work ability through SOC training. This training was primarily intended to acquaint nurses with the SOC model as well as stimulate the development of individual strategies by way of which they might actively address their own work ability. This was, according to the authors, the first such experiment.

\subsection{Work Ability Index (WAI)}

Work ability is a precondition for employees remaining healthy as well as their ability to stay in the workplace until retirement age (Müller et al., 2013, 1640). Ilmarinen $(2012,7)$ also points to the fact that the higher the working ability is upon retirement, the higher the quality of life is later on. Assessment of working ability detects a worker's risk factors at an early stage, thus permitting preventive measures to be formulated and implemented in a timely fashion. Accordingly, the assessment of work ability contributes to the preservation, restoration and support of working ability (Čeledová et al., 2014, 291). It, therefore, enables the early detection of those employees who have difficulties in meeting requirements arising from work. With the prolongation of retirement age, this is very important in the case of older employees in particular (Carel et al., 2013, 588).

In the field of nursing, there are numerous studies examining the association of WAI with various factors (Table 1).

Table 1: Results from previous WAI nurse research

\begin{tabular}{|c|c|c|c|}
\hline $\begin{array}{l}\text { Author } \\
\text { Year } \\
\text { Country }\end{array}$ & Sample & Factors & Results WAI \\
\hline $\begin{array}{c}\text { Golubic et al. } \\
2009 \\
\text { Croatia }\end{array}$ & $\mathrm{n}=1.086$ & $\begin{array}{l}\text { Work-related stress, edu- } \\
\text { cation }\end{array}$ & $\begin{array}{l}380(35 \%) \quad W A I<37 \\
706(65 \%) \quad W A I \geq 37\end{array}$ \\
\hline $\begin{array}{l}\text { Geukes et al., } \\
2011 \\
\text { Netherlands }\end{array}$ & $\mathrm{n}=208$ & Menopausal symptoms & $\begin{array}{c}\mathrm{M} \pm \mathrm{SD} \text { WAI } \\
38.69 \pm 6.16\end{array}$ \\
\hline $\begin{array}{c}\text { Milosevic et al. } \\
2011 \\
\text { Croatia }\end{array}$ & $\mathrm{n}=1.212$ & Quality of life & $\begin{array}{c}\mathrm{M} \pm \mathrm{SD} \text { WAI } \\
38.3 \pm 6.1\end{array}$ \\
\hline $\begin{array}{c}\text { Knezevic et al. } \\
2011 \\
\text { Croatia }\end{array}$ & $\begin{array}{c}\mathrm{n}=60 \text { (midwives) } \\
\mathrm{n}=98 \text { (pediatric nurses) }\end{array}$ & Work-related stress & $\begin{array}{c}\mathrm{M}=40.0 \text { (midwives) } \\
\mathrm{M}=37.5 \text { (pediatric nurses) }\end{array}$ \\
\hline $\begin{array}{c}\text { Habibi et al. } \\
2012 \\
\text { Iran }\end{array}$ & $\mathrm{n}=228$ & Physical work capacity & $\begin{array}{c}\mathrm{M} \pm \mathrm{SD} \text { WAI } \\
38.25 \pm 4.4\end{array}$ \\
\hline $\begin{array}{c}\text { Derycke et al. } \\
2012 \\
\text { Belgium }\end{array}$ & $\mathrm{n}=1.531$ & Turnover intention & $\begin{array}{c}\mathrm{M} \pm \mathrm{SD} \text { WAI } \\
40.3 \pm 4.8\end{array}$ \\
\hline $\begin{array}{l}\text { Magnago et al. } \\
2012, \\
\text { Brazil }\end{array}$ & $\mathrm{n}=498$ & $\begin{array}{l}\text { Intensity of musculoskel- } \\
\text { etal pain }\end{array}$ & $\begin{array}{c}\text { poor } 5.7(n=29) \\
\text { moderate } 37.6 \%(n=187) \\
\text { good } 41.4 \%(n=206) \\
\text { excellent } 15.3(n=76)\end{array}$ \\
\hline $\begin{array}{l}\text { Monteiro et al. } \\
2012 \\
\text { Brazil }\end{array}$ & $\mathrm{n}=570$ & Health and lifestyle & $\begin{array}{c}\mathrm{M} \pm \mathrm{SD} \text { WAI } \\
39.3 \pm 5.3\end{array}$ \\
\hline $\begin{array}{l}\text { Sorić et al. } \\
2013 \\
\text { Croatia }\end{array}$ & $\mathrm{n}=1.124$ & $\begin{array}{l}\text { Shift work and quality of } \\
\text { life }\end{array}$ & $\begin{array}{l}\text { Median WAI } \\
39(34-43)\end{array}$ \\
\hline
\end{tabular}


Table 1: Results from previous WAI nurse research (continued)

\begin{tabular}{|c|c|c|c|}
\hline $\begin{array}{c}\text { Fischer in Martinez } \\
2013 \\
\text { Brazil }\end{array}$ & $\mathrm{n}=514$ & $\begin{array}{l}\text { Working conditions and } \\
\text { work injuries }\end{array}$ & $\begin{array}{c}\mathrm{M} \pm \mathrm{SD} \text { WAI } \\
42.3 \pm 4.5\end{array}$ \\
\hline $\begin{array}{c}\text { Prochnow et al. } \\
2013 \\
\text { Brazil }\end{array}$ & $\mathrm{n}=498$ & $\begin{array}{l}\text { Psychological demands } \\
\text { and control over the work }\end{array}$ & $\begin{array}{c}45.8 \% \text { female workers and } 50.9 \% \\
\text { aged } \geq 47 \text { years presented reduced } \\
\text { work ability }(p<0.05)\end{array}$ \\
\hline $\begin{array}{c}\text { Carel et al. } \\
2013 \\
\text { Israel }\end{array}$ & $\mathrm{n}=515$ & $\begin{array}{l}\text { Sociodemographic factors } \\
\text { and illness factors }\end{array}$ & $\begin{array}{c}\mathrm{M} \pm \mathrm{SD} \text { WAI } \\
41.9 \pm 5.1\end{array}$ \\
\hline $\begin{array}{l}\text { Müller et al. } \\
2013 \\
\text { Germany }\end{array}$ & $\mathrm{n}=438$ & $\begin{array}{l}\text { SOC (selection, optimiza- } \\
\text { tion and compensation) }\end{array}$ & $\begin{array}{c}\mathrm{M} \pm \mathrm{SD}\left(1^{\text {st }} \text { item of the whole }\right. \\
\text { WAI }) \\
7.72 \pm 1.60\end{array}$ \\
\hline $\begin{array}{l}\text { Kordi et al. } \\
2014 \\
\text { Iran }\end{array}$ & $\mathrm{n}=123$ & Occupational stress & $\begin{array}{c}\mathrm{M} \pm \mathrm{SD} \text { WAI } \\
38.81 \pm 0.05\end{array}$ \\
\hline $\begin{array}{l}\text { Čeledová et al. } \\
2014 \\
\text { Czech Republic }\end{array}$ & $\mathrm{n}=53$ & $\begin{array}{l}\text { A comparison WAI results } \\
\text { with development com- } \\
\text { pany }\end{array}$ & $\begin{array}{c}\mathrm{M} \pm \mathrm{SD} \text { WAI } \\
36.3 \pm 6.1\end{array}$ \\
\hline $\begin{array}{l}\text { Nowrouzi et al. } \\
2015 \\
\text { Canada }\end{array}$ & $\mathrm{n}=111$ & Workplace system factors & $\begin{array}{c}21(29 \%) \mathrm{WAI}<37 \\
51(70.8 \%) \mathrm{WAI} \geq 37\end{array}$ \\
\hline $\begin{array}{l}\text { Jakobsen et al. } \\
2015 \\
\text { Denmark }\end{array}$ & $\begin{array}{c}\mathrm{n}=111 \text { (physical exercise } \\
\text { at work) } \\
\mathrm{n}=89 \text { (physical exercise } \\
\text { at home) }\end{array}$ & $\begin{array}{c}\text { Physical exercise at the } \\
\text { workplace }\end{array}$ & $\begin{array}{c}\mathrm{M}(\mathrm{WAI})=43.1 \\
\mathrm{M}(\mathrm{WAI}) \text { physical exercise: } \\
\text { at work }=42.8 \pm 4.6 \\
\text { at home }=43.3 \pm 4.2\end{array}$ \\
\hline $\begin{array}{c}\text { da Silva et al. } \\
2016 \\
\text { Brazil }\end{array}$ & $\mathrm{n}=100$ & Fatigue & $\begin{array}{c}\mathrm{M} \pm \mathrm{SD} \text { WAI } \\
39.4 \pm 6.0\end{array}$ \\
\hline $\begin{array}{c}\text { Sandeva and Koleva, } 2016 \\
\text { Bulgaria }\end{array}$ & $\mathrm{n}=63$ & Psychological Well-being & $\begin{array}{c}\mathrm{M} \pm \mathrm{SD} \text { WAI } \\
40.8 \pm 4.8\end{array}$ \\
\hline $\begin{array}{l}\text { Rostamabadi et al. } \\
2017 \\
\text { Iran }\end{array}$ & $\mathrm{n}=214$ & $\begin{array}{l}\text { Individual characteriza- } \\
\text { tions, workload, fatigue, } \\
\text { and diseases }\end{array}$ & $\begin{array}{c}\mathrm{M} \pm \mathrm{SD} \text { WAI } \\
39,80 \pm 5.0\end{array}$ \\
\hline $\begin{array}{l}\text { Converso et al. } \\
2018 \\
\text { Italy }\end{array}$ & $\mathrm{n}=333$ & Job and personal resources & $\begin{array}{l}\mathrm{M} \pm \mathrm{SD} \text { WAI } \\
38,27 \pm 5,67\end{array}$ \\
\hline
\end{tabular}

Note: $\mathrm{n}$ - numerus; WAI - Work Ability Index assessment; M - arithmetical mean value; SD - standard deviation.

Ability in the workplace is assessed using the Work Ability Index developed in the 1980 s by Tuomi et al. (1998) at the Finnish Institute of Occupational Health. This instrument is already being used in Slovenia by The University Rehabilitation Institute, Republic of Slovenia, which acquired the rights for non-commercial use (Tuomi et al., 2005).

\section{Methodology}

\subsection{Data and sample}

A quantitative research method was used in an empirical study to determine the association between the use of the SOC model and the WAI score by nurses aged 50 and over in secondary hospitals in Slovenia. According to the NIJZ (2018), in 2016, a total of 6.881 nurses of different educational levels were employed in the secondary hospitals. We wanted to include in our research all 21 hospitals (general 
and special) at a secondary level across Slovenia, but only 13 of them decided to participate in this research project, which was conducted between April and December 2016. Participation in the survey was voluntary, and a pre-condition for inclusion was that the individual was at least 50 years of age in 2016. We distributed 910 questionnaires. The response rate was $47.6 \%$. The sample in our study thus consisted of 433 nurses 50 years and older. Female nurses $(94.0 \%)$ predominated, and participants had an average age of $53.75 \pm 2.40$ years and career length of $33.62 \pm 3.29$ years. Few survey participants had 2 nd cycle academic education, $17.1 \%$ had 1 st cycle academic education, $6.5 \%$ had a higher vocational education, while the majority $(74.6 \%)$ had secondary education followed by nursing careers (Table 2).

Table 2: Description of the study sample $(n=433)$

\begin{tabular}{|c|c|c|c|}
\hline \multicolumn{2}{|r|}{ Demographic data } & \multirow{2}{*}{$\begin{array}{c}\text { f } \\
407\end{array}$} & \multirow{2}{*}{$\begin{array}{r}\mathbf{f}(\mathbf{\%}) \\
94.0\end{array}$} \\
\hline Gender & Female & & \\
\hline & Male & 26 & 6.0 \\
\hline \multirow[t]{11}{*}{ Age } & 50 & 44 & 10.2 \\
\hline & 51 & 47 & 10.9 \\
\hline & 52 & 50 & 11.5 \\
\hline & 53 & 65 & 15.0 \\
\hline & 54 & 63 & 14.5 \\
\hline & 55 & 57 & 13.2 \\
\hline & 56 & 48 & 11.1 \\
\hline & 57 & 30 & 6.9 \\
\hline & 58 & 17 & 3.9 \\
\hline & 59 & 8 & 1.8 \\
\hline & 60 & 4 & 0.9 \\
\hline \multirow[t]{5}{*}{ Education level } & Vocational upper secondary education & 3 & 0.7 \\
\hline & Technical upper secondary education & 323 & 74.6 \\
\hline & $\begin{array}{l}\text { Higher vocational education ( }\left(1^{\text {st }} \text { cycle profes- }\right. \\
\text { sional education })\end{array}$ & 28 & 6.5 \\
\hline & $1^{\text {st }}$ cycle academic education & 74 & 17.1 \\
\hline & $2^{\text {nd }}$ cycle academic education & 5 & 1.2 \\
\hline
\end{tabular}

Note: $\mathrm{n}$ - numerus; WAI - Work Ability Index assessment; M - arithmetical mean value; SD - standard deviation.

\subsection{Research instruments}

Two measurement instruments were used in the study.

The first was "Selection, Optimization, Compensation (SOC)-in-nursing-scale” devised by (Müller et al., 2013). The questionnaire, translated into Slovenian language by an official translator, comprised nine variables. In relation to each question, individual responses were measured according to the 5-point Likert scale. Participating nurses chose from the following predetermined responses: 1 "Entirely disagree", 2 - "Disagree", 3 - "Neither disagree nor agree", 4 - "Agree", 5 - "Entirely agree" (Table 4).

The second instrument (Appendix), designed to measure work ability (Tuomi, et al., 2005), is a shortened ver- sion enumerating fourteen groups of diseases, which differs in the third item of the questionnaire and the method of scoring (WAI-Netzwerk Deutschland, 2015a; WAI-Netzwerk Deutschland, 2015b). The result is an assessment or index of work ability, derived from scores ranging from 7 to 49 points (Table 3 ) in which decimals are rounded up. The overall self-assessment score of work ability is thence classified into one of four categories "poor" (7 to 27 points), "moderate" (28 to 36 points), "good" (37 to 43 points) and "excellent" (44 to 49 points). 
Table 3: Items covered by the WAI, the number of questions used to evaluate each item, and the scoring of the responses (short version of WAI)

\begin{tabular}{|c|c|c|c|}
\hline \multicolumn{2}{|r|}{ Items } & \multirow{2}{*}{$\begin{array}{c}\begin{array}{c}\text { Number of ques- } \\
\text { tions }\end{array} \\
1\end{array}$} & \multirow{2}{*}{$\begin{array}{c}\text { Scoring of the responses } \\
0-10 \text { points } \\
\text { (value circled in the questionnaire) }\end{array}$} \\
\hline 1 & $\begin{array}{c}\text { Current work ability compared to the best } \\
\text { work ability }\end{array}$ & & \\
\hline 2 & Work ability in relation to demands for work & 2 & $\begin{array}{l}\text { score weighted according to the nature of the } \\
\text { work* }\end{array}$ \\
\hline 3 & $\begin{array}{c}\text { Diagnosed diseases } \\
\text { (only diseases diagnosed by a physician are } \\
\text { counted) }\end{array}$ & $\begin{array}{l}1 \\
\begin{array}{l}\text { (list of } 14 \text { disease } \\
\text { groups) }\end{array}\end{array}$ & $\begin{array}{c}7 \text { points }=\text { no disease } \\
5 \text { points }=1 \text { disease } \\
3 \text { points }=2 \text { diseases } \\
3 \text { points }=3 \text { diseases } \\
1 \text { point }=4 \text { diseases } \\
1 \text { point }=5 \text { and more diseases }\end{array}$ \\
\hline 4 & Estimated work impairment due do diseases & 1 & $\begin{array}{l}1-6 \text { points } \\
\text { (value circled in the questionnaire; the worst } \\
\text { value should be chosen) }\end{array}$ \\
\hline 5 & $\begin{array}{l}\text { Sick leave during the past year } \\
\text { (12 months) }\end{array}$ & 1 & $\begin{array}{c}1-5 \text { points } \\
\text { (value circled in the questionnaire) }\end{array}$ \\
\hline 6 & $\begin{array}{c}\text { Own prognosis of work ability two years from } \\
\text { now }\end{array}$ & 1 & $\begin{array}{c}1,4 \text { or } 7 \text { points } \\
\text { (value circled in the questionnaire) }\end{array}$ \\
\hline 7 & $\begin{array}{c}\text { Mental resources } \\
\text { (item } 7 \text { refers to the worker's life in general, } \\
\text { both at work and during leisure time) }\end{array}$ & 3 & $\begin{array}{l}\text { The points of the question series are added } \\
\text { together, and the sum is modified as follows: } \\
\text { sum } 0-3=1 \text { point } \\
\text { sum } 4-6=2 \text { points } \\
\text { sum } 7-9=3 \text { points } \\
\text { sum } 10-12=4 \text { points }\end{array}$ \\
\hline
\end{tabular}

Note: * weighted in accordance with instructions (Tuomi et al., 1998)

\subsection{Statistical analyses}

Consent to carry out this research was obtained from the management of the participating hospitals. The survey was conducted anonymously, and participation was voluntary.

Depending upon the decision of the individual hospital, questionnaires were dispatched and received in person or by mail in a sealed envelope. Data from the questionnaires was processed using IBM SPSS ver. 22.0. The results are indicated and assessed in a series of tables and graphs.

Descriptive statistics were used to illustrate the comparison of SOC strategies as per Müller et al. (2013), and likewise, the results have been presented as the arithmetical mean of the responses $(\mathrm{M})$ together with the standard deviation (SD).

The correlation between the mean of the SOC results of our research and that of Müller et al. (2013) was calculated using the Spearman's correlation coefficient (rs) of the arithmetical mean values of the SOC items presented in Table 4. The method used in our research was identical to Müller et al. (2013, 1632, paragraph 6) methodology. Items have the same meaning, and the levels of the values are the same as Müller et al. (2013, 1636, Table 3).

To calculate the relationship between the use of SOC and WAI in our study, a Spearman's correlation coefficient was also applied.

\section{Results}

The results in Table 4 provide the answer to the first research question: "Are there differences in the mean value of SOC results between our research and the research of Müller et al. (2013)?" The arithmetical mean value (M) and the standard deviation (SD) were calculated in relation to the answers provided. 
Table 4: Items of SOC model applied in the workplace by nurses over fifty working in Slovenian hospitals and nurses in research of Müller et al. (2013)

\begin{tabular}{|c|c|c|c|c|}
\hline \multirow[t]{2}{*}{ SOC items } & \multicolumn{2}{|c|}{$\begin{array}{l}\text { Our research, } 2016 \\
(n=433)\end{array}$} & \multicolumn{2}{|c|}{$\begin{array}{l}\text { Müller et al., } 2013 \\
(n=438)\end{array}$} \\
\hline & $\mathrm{M}$ & $\mathrm{SD}$ & $\mathrm{M}$ & $\mathrm{SD}$ \\
\hline At work I always carry out my most important tasks first (S) & 4.17 & 0.71 & 4.23 & 0.64 \\
\hline $\begin{array}{l}\text { Also, in stressful work situations, I perform one task after another } \\
\text { (S) }\end{array}$ & 3.88 & 0.80 & 3.62 & 0.89 \\
\hline I concentrate on the most important tasks to do my job well (S) & 4.18 & 0.62 & 4.15 & 0.64 \\
\hline I do exercises to accomplish the physical demands in nursing $(\mathrm{O})$ & 3.11 & 0.99 & 3.57 & 1.04 \\
\hline $\begin{array}{l}\text { I keep myself constantly informed about the current professional } \\
\text { knowledge in nursing }(\mathrm{O})\end{array}$ & 3.73 & 0.70 & 3.31 & 0.93 \\
\hline I deliberately use back-friendly working techniques $(\mathrm{O})$ & 3.42 & 0.81 & 3.30 & 0.93 \\
\hline I ask for help to accomplish heavy physical tasks (C) & 3.72 & 0.86 & 3.97 & 0.88 \\
\hline I use external aids to accomplish heavy physical tasks (C) & 2.44 & 0.98 & 3.25 & 1.21 \\
\hline $\begin{array}{l}\text { I organize my work in a way that allows me to counterbalance } \\
\text { one-sided physical stressors (C) }\end{array}$ & 3.38 & 0.88 & 3.12 & 0.93 \\
\hline
\end{tabular}

Note: S - Selection; O - Optimization; C - Compensation; $\mathrm{M}$ - arithmetical mean value; SD - standard deviation.

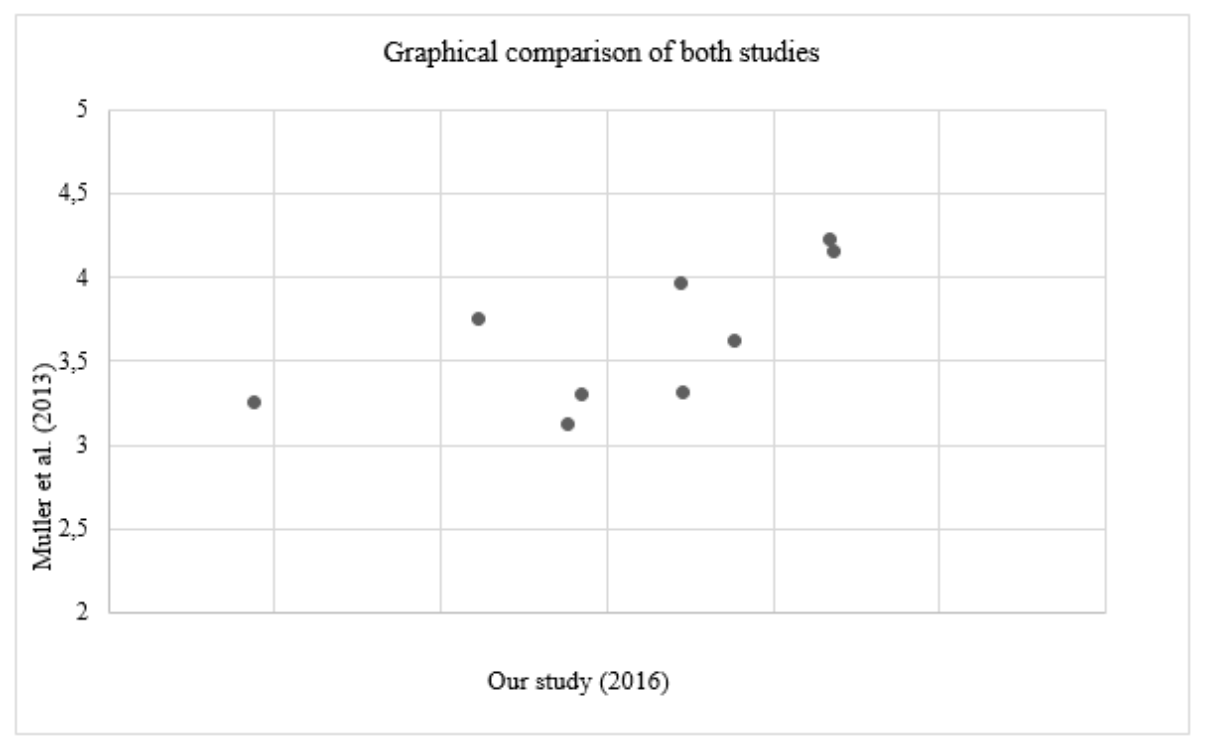

Figure 1: Comparison of nine SOC items of the study by Müller et al. (2013) and our own study 
Our study also intended to ascertain whether the use of the SOC model in nursing care alters with age. The results displayed as the arithmetical mean value (M) and standard deviation (SD) for the total SOC model estimate and each individual SOC model variable are shown in Table 5.

Table 5: Application of SOC strategies by age

\begin{tabular}{|c|c|c|c|c|c|c|c|c|}
\hline Age & M soc & SD soc & M s & SD s & M o & SD o & M c & SD c \\
\hline 50 & 3.51 & 0.44 & 3.86 & 0.57 & 3.49 & 0.68 & 3.17 & 0.58 \\
\hline 51 & 3.60 & 0.54 & 4.00 & 0.64 & 3.51 & 0.66 & 3.29 & 0.84 \\
\hline 52 & 3.52 & 0.49 & 4.13 & 0.59 & 3.39 & 0.65 & 3.03 & 0.78 \\
\hline 53 & 3.58 & 0.45 & 4.23 & 0.49 & 3.36 & 0.60 & 3.16 & 0.70 \\
\hline 54 & 3.50 & 0.48 & 4.03 & 0.61 & 3.34 & 0.61 & 3.13 & 0.60 \\
\hline 55 & 3.57 & 0.48 & 4.15 & 0.61 & 3.39 & 0.63 & 3.16 & 0.68 \\
\hline 56 & 3.48 & 0.45 & 3.98 & 0.63 & 3.35 & 0.66 & 3.13 & 0.70 \\
\hline 57 & 3.56 & 0.38 & 4.01 & 0.57 & 3.40 & 0.48 & 3.27 & 0.48 \\
\hline 58 & 3.80 & 0.42 & 4.31 & 0.49 & 3.65 & 0.63 & 3.40 & 0.51 \\
\hline 59 & 3.74 & 0.35 & 4.25 & 0.56 & 3.75 & 0.61 & 3.21 & 0.75 \\
\hline 60 & 4.00 & 0.55 & 4.17 & 0.33 & 3.92 & 0.96 & 3.92 & 0.50 \\
\hline Average & $\mathbf{3 . 6 2}$ & $\mathbf{0 . 4 7}$ & $\mathbf{4 . 1 0}$ & $\mathbf{0 . 5 9}$ & $\mathbf{3 . 5 0}$ & $\mathbf{0 . 6 3}$ & $\mathbf{3 . 2 6}$ & $\mathbf{0 . 6 8}$ \\
\hline
\end{tabular}

Note: M - arithmetical mean value; SD - Standard deviation; SOC - Selection, Optimisation, Compensation model; S - Selection; $\mathrm{O}$ - Optimisation; C - Compensation.

The results, in the form of arithmetical mean values (M), are displayed graphically in Figure 2 and reveal the relationship of individual SOC components and SOC as a whole, by nurses aged 50-60 in Slovenia.

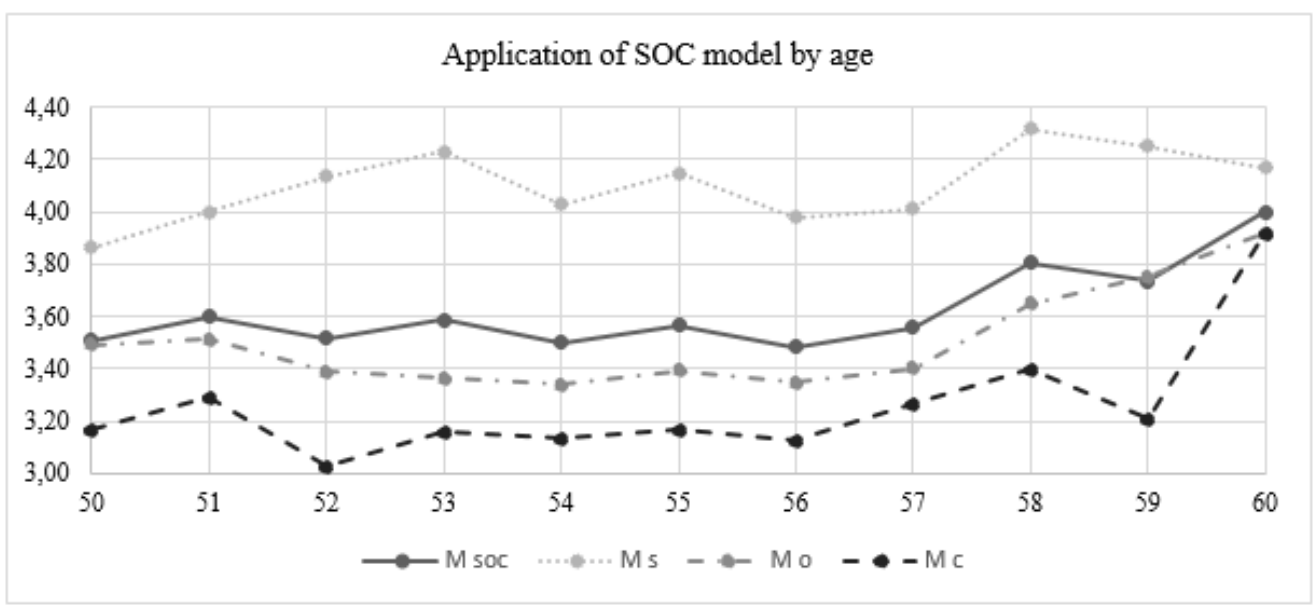

Figure 2: Results of the application of SOC by Slovenian nurses aged between fifty and sixty

Note: $\mathrm{M}$ - arithmetical mean value; SOC - Selection, Optimisation, Compensation; S - Selection; O - Optimisation; C - Compensation. 
To analyze the functional relation between the use of SOC (dependent value, denoted by $\mathrm{Y}$ ) and calendar age (independent value, denoted by $\mathrm{X}$ ), we used the calculated SOC values of all respondents and analyzed their linear and potential regression function (Figure 3 ).

Table 6 presents the calculated coefficients of the regression functions and a standard error of the estimate values. It was established that both regression functions have the same standard deviation from the SOC values, and therefore their quality of approximation of the original is equal. We conclude that in our research, the use of SOC is slightly growing with the calendar age of the nurse by the slope $\mathrm{a}=0.0044$. This coefficient can't be generalized $(\mathrm{p}=0.64)$.

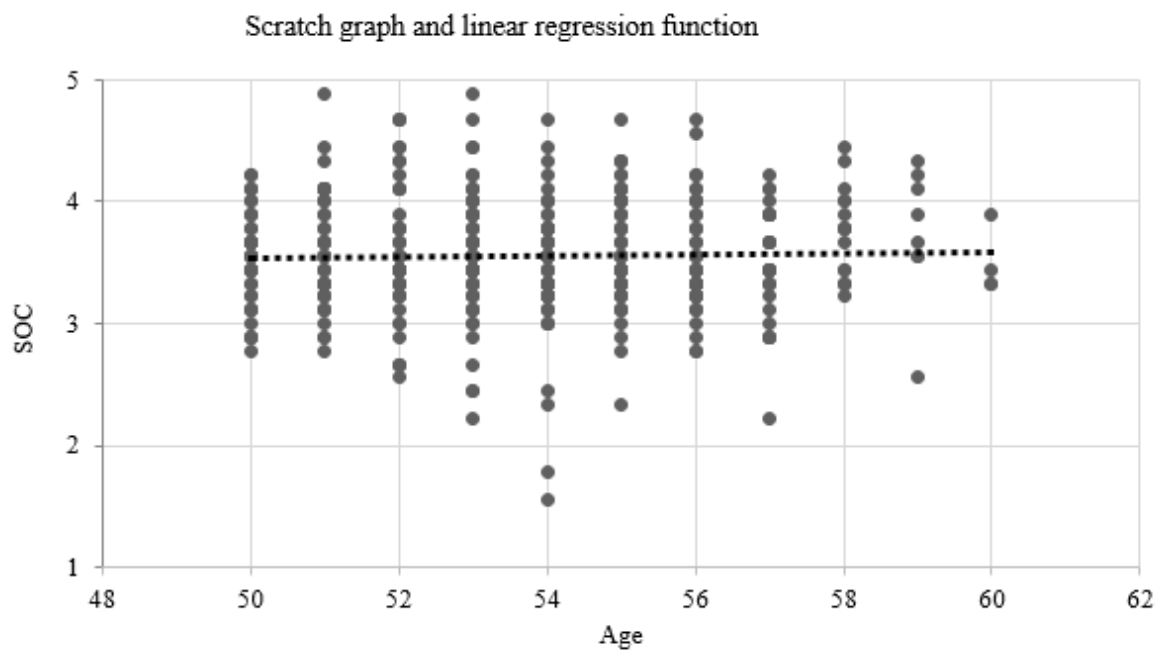

Figure 3: Use of SOC in relation to Age (in years) of nurses aged over fifty

Table 6: Determination of regression function values

\begin{tabular}{cccc}
\hline & \multicolumn{2}{c}{ Coefficients of the regression model } & \\
\cline { 2 - 3 } Type of function & $\mathrm{a}$ & $\mathrm{b}$ & $\begin{array}{c}\text { Std. Error of the } \\
\text { Estimate }\end{array}$ \\
\hline Linear regression model: & 0.0044 & 3.3205 & 0.4678 \\
$\mathrm{Y}=\mathrm{aX}+\mathrm{b}$ & & & 0.4678 \\
\hline Potential regression model: & 2.741941 & 0.06542 & \\
\hline
\end{tabular}

The last research question of the study was to relate SOC model use and WAI by nurses over fifty years of age in Slovenia. Calculated WAI according to Table 2 by nurses in our study is fairly low: the average is classified as borderline "good" to "moderate" $(\mathrm{M}=36.98 \pm 6.46$ and $\mathrm{Me}=$ 38). The relationship between SOC model use arithmetical mean values (M) and WAI assessment of Slovenian nurses aged fifty to sixty is presented graphically in Figure 4.
The Spearman correlation coefficient (rs) of the SOC and WAI variables $(\mathrm{rs}=0.23)$ of all respondents was calculated. Our research confirms that the SOC and WAI correlation is positive and monotonic. According to Sheskin (2004, 956), the correlation is considered to be weak. Work ability of nurses increases with their application of SOC strategies. 


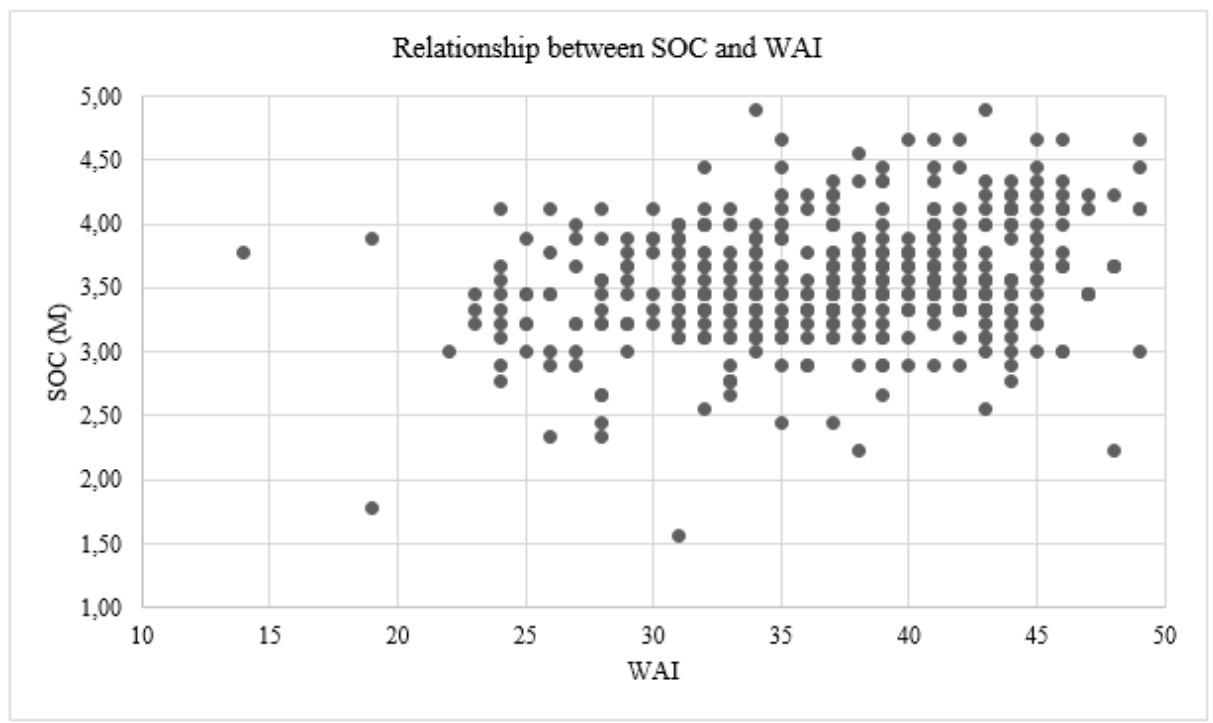

Figure 4: The relationship between SOC (M) and WAI assessment

\section{Discussion and conclusions}

Depending upon demographic indicators, it appears likely that much attention shall be devoted to the creation and application of strategies intended to manage the aging of health sector employees in order to ensure that they qualitatively and effectively carry out their vocation to retirement. Indeed, in order to ensure the future full provision of health care services, such strategies shall be essential in the prevention of early retirement and enable nurses to remain in the workplace even after reaching retirement age.

The first objective of our study was to apply the "SOCin-nursing-scale" in our environment and compare the results with Müller et al. (2013). Indeed, the findings are similar, and there exists a strong correlation between the two sets of results. A difference between our study and the research carried out by Müller (2013) is the age differential in the study groups. Our study encompassed nurses aged between fifty and sixty $(M=53.75)$, while the age of respondents in Müller et al. (2013) ranged between 21 and 63 years $(\mathrm{M}=38.5)$.

We were also interested to find out which element of the SOC is most commonly used by nurses fifty and over in Slovenia. Participants in our study make the most use of selection and compensation the least. We found out that the use of SOC significantly increases at the age of 58 and is highest at 60 years of age. The element of SOC mostly used by nursing care providers in our study is "selection," which achieves a peak at 58 years. The use of "optimization" is somewhat higher at 51 years, then falls slightly and rises considerably at 58 before peaking at 60 years. "Compensation" is the least used SOC element in our study; its use is lowest at 52 years, but increases significantly at 58 years, then falls at 59 years before rising abruptly at 60 years. It was established that the participants in our research were heavily focused on carrying out their work. The vast majority focused on the "selection" of the most important tasks, as well as carrying out the most important tasks first; in stressful situations, they performed one task after another. This group of claims was also the highest-rated. The second group of claims pertained to individual optimization in achieving goals. Most participants in the study indicated that their professional education was ongoing and that they consciously employed techniques of compensation to protect the spine as well as undertook regular physical exercise. The final three assertions pertaining to physical tasks revealed that participants in the survey most often asked for help in performing heavy labor, organized their work in such a way that the physical burden is evenly distributed and mitigated the accomplishment of heavy physical tasks. The statement: "I use external aids to accomplish heavy physical tasks," was rated most poorly by the participants in this study. The last three compensation-related items in our survey were the lowest-scored strategies of the SOC strategy, which is alarming.

Müller et al. (2013, 1636) established that the application of the adapted SOC model exerts a positive impact on the work ability of nurses (the positive relationship between optimization/ compensation in nursing and work ability was stronger by older nurses). Also, we find a positive monotonic relationship between the use of SOC strategies and WAI assessment. In our study, we find a lower average WAI score $(\mathrm{M}=36.98 \pm 6.46)$ than in the studies of others; in our case, there was also a higher average age of the study's participants (Table 3). It is important to note that Müller et al. (2013) did not use the overall WAI 
in their study, but the assessment of current work ability (grade 0 to 10) instead, which is the first point of the WAI measurement instrument (where $\mathrm{M}=7.72 \pm 1.60$ ), and is also an objective indicator of work ability. Other authors similarly note the correlation between current assessments of working ability and a complete assessment of WAI (El Fassi et al., 2013; Mokarami et al., 2016).

SOC has also been researched by other authors. von Bonsdorff et al. $(2014,326)$ established that the application of the SOC model influenced the relationship between organizational equity and working ability, thus an elevated presence of organizational equity promotes the use of SOC and thus helps employees maintain their working ability in the latter stages of their career. Baethge et al. (2016) ascertained the efficacy of selective optimization through the implementation of compensatory practices in the workplace by health care providers subject to heavy workloads. However, Müller et al. (2015) who tried to influence working ability through SOC training, did not ascertain any statistically significant influence of such training on the work ability of nursing staff.

Given that the respondents in our study were least concerned with "compensation," we suggest exploring options in working environments to improve ergonomic working conditions and to obtain enough working aids. It is also important to assemble work teams that are multi-generational. According to Rožman et al. (2017), it is important for managers to be aware of the age diversity of their employees and their needs.

Older nurses often have certain deficits associated with physical health and degenerative changes, while younger ones lack experience. Cooperation and support are certainly effective compensation mechanisms for nursing work. In this context, it is necessary to promote this important aspect of compensation in the work teams.

Research by Rožman et al. (2017), which found differences in burnout symptoms between younger (18 to 49 years) and older (50 to 65 years) employees in different Slovenian work organizations $(n=400)$, showed that older employees are more susceptible to physical symptoms of burnout. The authors also point out that reduced work capacity is associated with high physical workloads. Older employees need to be provided with the necessary adjustments to the work environment due to early retirement or work disability.

Nursing work is physically and mentally demanding and using SOC strategies could allow employees to have fewer problems related to the psychophysical factors of work. As a result, work outcomes are also better. Therefore, the use of SOC strategies in work environments needs to be promoted. It is important for management to recognize the benefits of using selection, optimization and compensation and to motivate their employees to take advantage of these opportunities in their work. Nurses need to be acquainted with SOC strategies and taught to use them.
Rožman et al. (2019) emphasize that working conditions need to be adapted to all employees and jobs should be developed according to the age diversity of employees, with the workload adapted to all age groups, since not all employees experience job characteristics in the same way.

Very important is that nursing management should be aware that SOC strategies work well in a supportive environment introduced by management. Older people generally have sufficient resources and reserves to optimize, but they often encounter an overly protective or restrictive working environment that inhibits such optimization. There is no doubt that the optimization process is conditioned by the promotion and improvement of environmental conditions (Baltes and Carstensen 1996, 412). Consequently, it is necessary to plan and implement healthy environments for nurses in the latter stages of their careers, to prepare ergonomic assessments of the working environment, and to identify the gaps between the requirements of the workplace and the capacities of an individual worker (Randolph 2013, 548). All such measures impact the work ability of employees.

Our study, which included nurses over fifty years old working in Slovenian hospitals, found that the use of SOC strategies and WAI assessment were positively correlated. The need to employ SOC strategies increases significantly at the age of 58 years and it grows to the age of 60 . Given that the retirement age is increasing and will reach 65 years for both genders in the near future, the need for adaptation of the work environment will be further intensified in hospital care.

The assessment of work ability in our research indicates the need for such measures and the implementation of successful aging strategies for nurses in the workplace.

Nursing management must be aware, that through creating successful aging strategies, we will contribute to the successful aging of nurses. Intuitively, SOC strategies are applied in every circumstance across all ages and at every stage of life. Presented SOC strategies are just a proposal that can be used to design work regimes in nursing care to improve the WAI and to provide successful aging. For management in nursing care, it is essential that individual working units formulate their own selection, optimization and compensation strategies that are structured to the work demands and age structure of the employees.

It is also necessary to develop tools for evaluating the impact of these strategies. The WAI provides one option for evaluating the effectiveness of future measures introduced into the nursing care environment in order to make it easier for older nurses to continue to achieve their personal and professional goals.

According to the Nursing Chamber of Slovenia, in January 2017, one-third ${ }^{1}$ of Slovenian nurses have already reached the age of 50; strategies for successful aging in

${ }^{1}$ Data from the register was obtained by e-mail from the Nursing Chamber of Slovenia in February 2017. 
nursing settings have not been implemented yet. There is also a lack of research in this field of nursing in Slovenia.

Based on the measured index of work ability in our research, it can be concluded that concrete measures in terms of improved working conditions and organizational factors should be taken immediately. Nurses 50 years and older in Slovenia need the possibility to do "selection," "optimization" and "compensation," and this is what nursing management has to offer.

Our research is just one option and a starting point for further research. For a broader view of the nursing situation, research should be extended to the primary and tertiary levels of healthcare and determine whether our results are valid on these two healthcare levels.

Further research is needed to show what specifically nurses of 50 years and over in Slovenia need, where are they most at risk and what measures should be taken. Only based on concrete results will it be possible to devise appropriate strategies for successful aging that will suit our actual nursing environment.

This research was limited to the nurses aged over fifty who provide nursing care in secondary hospitals. Although the number of responses is high $(n=433)$, the response rate was only $47.6 \%$. A significant drawback of the survey was the low number of respondents over the age of 57 , which made statistical inference difficult. The research was designed as a cross-sectional study therefore it cannot provide a longitudinal view to the subject of the research. In the future, a longitudinal study would be welcome to study SOC strategies and its effect on the work ability of nurses over fifty.

\section{Literature}

Baethge, A., Müller, A., \& Rigotti, T. (2016). Nursing performance under high workload: a diary study on the moderating role of selection, optimization and compensation strategies. Journal of Advanced Nursing, 72(3), 545-557, http://doi.org/10.1111/jan.12847

Baltes, M. M., \& Carstensen, L. L. (1996). The Process of Successful Ageing. Ageing and Society, 16, 397422, https://doi.org/10.1017/S0144686X00003603

Baltes, P. B. (1997). On the Incomplete Architecture of Human Ontogeny : Selection, Optimization, and Compensation as Foundation of Developmental Theory. American Psychologist, 52(4), 366-280, https://psycnet.apa.org/doi/10.1037/0003-066X.52.4.366

Baltes, P. B., \& Baltes, M. M. (1990). Psychological perspectives on successful aging: the model of selective optimization with compensation. V Successful Aging: Perspectives from the Behavioral Sciences. (1-34). Cambridge: Cambridge University Press, http://doi.org/10.1017/CBO9780511665684

Bosnes, I., Nordahl, H. M., Stordal, E., Bosnes, O., Myklebus, T. A., \&Almkvist, O. (2019). Lifestyle predictors of successful aging: A 20year prospective HUNT study. PLoS ONE,
14(7): 1-12, https://doi.org/10.1371/journal.pone.0219200

Britton, A., Shipley, M., Singh-Manoux, A., \& Marmot, M. G. (2008). Successful Aging: The Contribution of Early-Life and Midlife Risk Factors. JAGS, 56 (6), 10981105, https://doi.org/10.1111/j.1532-5415.2008.01740.x Carel, R. S., Zusman, M., \& Karakis, I. (2013). Work ability index in Israeli hospital nurses: applicability of the adapted questionnaire. Experimental Aging Research, 39, 579-590, http://doi.org/10.1080/0361073X.2013.839316

Cheung, F., \& Wu, A. M. (2012). An investigation of predictors of successfulaging in the workplace among Hong Kong Chinese older workers. International Psychogeriatrics, 24 (3), 449-464, https://doi.org/10.1017/S104161021100192X

Converso, D., Sottimano, I., Guidetti, G., Loera, B., Cortini, M., \& Viotti, S. (2018). Aging and Work Ability: The Moderating Role of Job and Personal Resources. Frontiers in Psychology, 8:2262, 2-12, $\quad$ http://doi.org/10.3389/fpsyg.2017.02262

Čeledová, L., Babková, K., Rogalewicz, V., \& Čevela, R. (2014). The Work Ability Index for persons aged $50+$ as an instrument for implementing the concept of Age Management. Kontakt, 16(4), 286292, http://doi.org/10.1016/j.kontakt.2014.10.003

da Silva, F. J., Felli, V. E.A., Martinez, M. C., Mininel, V. A., \& Pelegrini Ratie, A. P. (2016). Association between work ability and fatigue in Brazilian nursing workers. Work, 53, 225-232, http://doi.org/10.3233/WOR-152241

Derycke, H., Clays, E., Vlerick, P., D'Hoore, W., Hasselhorn, H. M., \& Braeckman, L. (2012). Perceived work ability and turnover intentions: a prospective study among Belgian healthcare workers. Journal of Advanced Nursing, 68(7), 1556-1566, http://doi.org/10.1111/j.1365-2648.2012.05961.x

El Fassi, M., Bocquet, V., Majery, N., Lair, M. L., Couffignal, S., \& Mairiaux, P. (2013). Work ability assessment in a worker population: comparison and determinants of Work Ability Index and Work Ability score. BMC Public Health 13:305, 1-10. Retrieved from http://www.biomedcentral.com/1471-2458/13/305 (Accessed 16.5.2019).

Fischer, F. M., \& Martinez M. C. (2013). Individual features, working conditions and work injuries are associated with work ability among nursing professionals. Work, 45, 509-517. http://doi.org/10.3233/WOR-131637.

Geukes, M., van Aalst, M. P., Nauta, M. C., \& Oosterhof, H. (2012). The impact of menopausal symptoms on work ability. The Journal of The North American Menopause Society, 19(3), 1-5, http://doi.org/10.1097/gme.0b013e31822ddc97

Golubic, R., Milosevic, M., Knezevic, B., \& Mustajbegovic, J. (2009). Work-related stress, education and work ability among hospital nurses. Journal of Advanced Nursing, 65(10), 2056-2066, http://doi.org/10.1111/j.1365-2648.2009.05057.x

Gopinath, B., Kifley, A., Flood, V. M. \& Mitchell, P. (2018). Physical Activity as a Determinant of Successful Aging over Ten Years. Scientific Reports, 8:10522, 1-5, $\quad$ http://doi.org/10.1038/s41598-018-28526-3

Gureje, O., Oladeji, B. D., Abiona, T., \& Chatterji, S. (2014). Profile and Determinants of Successful 
Aging in the Ibadan Study of Ageing. $J$ Am Geriatr Soc, 62, 836-842, http://doi.org/10.1111/jgs.12802

Habibi, E., Dehghan, H., Zeinodini, M., Yousefi, H., \& Hasanzadeh, A. (2012). A Study on Work Ability Index and Physical Work Capacity on the Base of Fax Equation VO2 Max in Male Nursing Hospital Staff in Isfahan, Iran. International Journal of Preventive Medicine, 3(11), 776-782. Retrived from https://www.ncbi.nlm.nih. gov/pmc/articles/PMC3506089/ (Accessed 16.5.2019).

Havighurst, R. J. (1961). Successful Aging. The Gerontologist, 1(1), 8-13, https://doi.org/10.1093/geront/1.1.8

Ilmarinen, J. (2012). Promoting active aging in the workplace. Retrieved from https:/osha.europa.eu/sl/.../promoting-active-ageing-in-the-workplace (Accessed 16.8.2015).

Jakobsen, M. D., Sundstrup, E., Brandt, M., Jay, K., Aagaard, P., \& Andersen, L. L. 2015. Physical exercise at the workplace prevents deterioration of work ability among healthcare workers: cluster randomized controlled trial. BMC Public Health, 15:1174, 1-9, http://doi.org/10.1186/s12889-015-2448-0

Knezevic, B., Milosevic, M., Golubic, R., Belosevic L., Russo, A., \& Mustajbegovic, J. (2011). Work-related stress and work ability among Croatian university hospital midwives. Midwifery, 27, 146153, https://doi.org/10.1016/j.midw.2009.04.002

Kordi, M., Mohamadirizi ,S., Shakeri, M. T., Modares Gharavi, M., \& Salehi Fadardi. J. (2014). The Relationship between Occupational Stress and Work Ability among Midwives in Mashhad, Iran. Journal of Midwifery and Reproductive Health, 2(3):188194, https://dx.doi.org/10.22038/jmrh.2014.2792

Lee, P.-L., Lan, W., \& Yen, T.-W. (2011). Aging Successfully: A Four-Factor Model. Educational Gerontology, 37, 210-227, http://doi.org/10.1080/03601277.2010.487759

Lin, P.-S., Hsieh, C.-C., Cheng, H.-S., Tseng, T.-J., \& Su, S.-C. (2016). Association between Physical Fitness and Successful Aging in Taiwanese Older Adults. PLoS ONE, 11(3), 1-12. doi:e0150389, http://doi.org/10.1371/journal.pone.0150389

Long, C., \& Griffiths, E. (2013). Britain's ageing NHS workforce. Occupational Health, 65(7), 18-20. Retrived from https:/www.personneltoday.com/hr/the-implications-of-britains-ageing-nhs-workforce/(Accessed 20.6.2019).

Magnago, T.S.B.S., Lima, A. C. S., Prochnow, A., Ceron, M. D. S., Tavares, J. P. \& Urbanetto J. S. (2012). Intensity of musculoskeletal pain and (in) ability to work in nursing. Rev. Latino-Am. Enfermagem, 20(6), 1125-33, http://dx.doi.org/10.1590/S0104-11692012000600015

Martin, A. S., Distelberg, B. J., \& Elahad, J. A. (2015). The Relationship Between Family Resilience and Aging Successfully. The American Journal of Family Therapy, 43:163179, http://doi.org/10.1080/01926187.2014.988593

Maurits, E. E. M., de Veer, A. J. E., van der Hoek, L. S., \& Francke, A. L. (2015). Factors associated with the self-perceived ability of nursing staff to remain working until retirement: a questionnaire survey. BMC Health Services Research 15:356, 1-11, http://doi.org/10.1186/s12913-015-1006-x Milosevic, M., Golubic, R., Knezevic, B., Golubic, K., Bubas, M., \& Mustajbegovic, J. (2011). Work abili- ty as a major determinant of clinical nurses' quality of life. Journal of Clinical Nursing, 20, 2931-2938, http://doi.org/10.1111/j.1365-2702.2011.03703.x Moghimi,D.,Zacher,H.,Scheibe,S., \&VanYperen,N.W.(2017). The selection, optimization, and compensation model in the work context: A systematic review and meta-analysis of two decades of research. Journal of Organizational Behavior, 38(2), 247-275, https://doi.org/10.1002/job.2108

Mokarami, H., Mortazavi, S. B., Asgari, A., \& Choobineh, A. (2016). Work Ability Score (WAS) as a Suitable Instrument to Assess Work Ability Among Iranian Workers. Health Scope. inpress(inpress), 1-8, $\quad$ http://doi.org/10.17795/jhealthscope-42014

Monteiro, I., Chillida, M. deS.P., \& Contrera Moreno, L. (2012). Work ability among nursing personnel in public hospitals and health centers in Campinas - Brazil. Work, 41, 316-319, http://doi.org/10.3233/WOR-2012-0176-316

Müller, A., Heiden, B., Herbig, B., Poppe, F., \& Angerer, P. (2015). Improving Well-Being at Work: A Randomized Controlled Intervention Based on Selection, Optimization, and Compensation. Journal of Occupational Health Psychology, 1-13, http://doi.org/10.1037/a0039676

Müller, A., Weigl, M., Heiden, B., Glaser, J., \& Angerer, P. (2012). Promoting work ability and well-being in hospital nursing: The interplay of age, job control, and successful ageing strategies. Work, 41, 51375144, http://doi.org/10.3233/WOR-2012-0083-5137

Müller, A., Weigl, M., Heiden, B., Herbig, B., Glaser, J., \& Angerer, P. (2013). Selection, optimization, and compensation in nursing: exploration of job-specific strategies, scale development, and age-specific associations to work ability. Journal of Advanced Nursing, 69 (7): 1630-1642, http://doi.org/10.1111/jan.12026

Nowrouzi, B., Lightfoot, N, Carter, L., Larivère, M., Rukholm, E., \& Belanger-Gardner, D. (2015). Workplace System Factors of Obstetric Nurses in Northeastern Ontario, Canada: Using a Work Disability Prevention Approach. Safety and Health at Work, 6, 305-311, https://doi.org/10.1016/j.shaw.2015.07.004

NIJZ. (2018). Zdravstveni statistični letopis Slovenije 2016 [Health Statistical Yearbook of Slovenia 2016]. Retrieved from https:/www.nijz.si/sites/www. nijz.si/files/uploaded/publikacije/letopisi/2016/8 viri_v_zdravstvu_2016.pdf (Accessed 10. 11. 2019).

Nimrod, G., \& Ben-Shem, I. (2015). Successful Aging as a Lifelong Process. Educational Gerontology, 41, 814824, http://doi.org/10.1080/03601277.2015.1050904

Parish, A., Kim, J., Lewallen, K. M., Miller, S, Myers, J., Panepinto, R., \& Maxwell, C. A. (2019). Knowledge and perceptions about aging and frailty: An integrative review of the literature. Geriatric Nursing, 40(1), 13-24, http://doi.org/10.1016/j.gerinurse.2018.05.007

Prochnow, A., Magnago T. S. B. S., Urbanetto, J. S., Beck C. L. C., Lima, S. B. S., \& Greco, P. B. T. (2013). Work ability in nursing: relationship with psychological demands and control over the work. Rev. Latino-Am. Enfermagem, 21(6), 1298-305, http://doi.org/10.1590/0104-1169.3072.2367

Randolph, S. A. (2013). Planning for Older Workers. Workplace Health Saf, 61(12), 548, http://doi.org/10.1111/ 
jonm.1206610.3928/21650799-20131107-01

Rostamabadi, A., Zamanian, Z., \& Sedaghat, Z. (2017). Factors associated with work ability index (WAI) among intensive care units' (ICUs') nurses. J Occup Health, 59, 147-155, http://doi.org/10.1539/joh.16-0060-OA

Rowe, J. W., \& Kahn, R. L. (1997). Successful Aging. The Gerontologist, 37 (4): 433440, https://doi.org/10.1093/geront/37.4.433

Rožman, M., \& Tominc, P. (2014). Upravljanje starostne raznolikosti na delovnih mestih [Management of Age Diversity at the Workplace]. Naše gospodarstvo / Our Economy, 60 (5-6), 3-11, http://doi.org/10.7549/ourecon.2014.5-6.01

Rožman, M., Treven, S., Čančer, V., \& Cingula, M. (2017). Burnout of Older and Younger Employees - The Case of Slovenia. Organizacija, 50 (1), 47-62, http://doi.org/10.1515/orga-2017-0005

Rožman, M., Grinkevich, A., \& Tominc, P. (2019). Occupational Stress, Symptoms of Burnout in the Workplace and Work Satisfaction of the Age-diverse Employees. Organizacija, 52 (1), 46-59, http://doi.org/10.2478/orga-2019-0005

Sandeva, G., \& Koleva, K. (2016). Work ability and psyhological well-being in hospital staff. CBU International Conference on Innovations in Science and Education. March 23-25, 2016, Prague, Czech Republic, 750-755, http://dx.doi.org/10.12955/cbup.v4.844

Sheskin, D.J.(2004). Handbookofparametricandnonparametric statistical procedures- $3^{\text {rd }}$ Ed. Chapman \& HALL/CRC.

Sorić, M., Golubić, R., Milošević, M., Juras, K., \& Mustajbegović, J. (2013). Shift Work, Quality of Life and Work Ability among Croatian Hospital Nurses. Coll. Antropol, 37(2), 379-384. Retrieved from https:// pdfs.semanticscholar.org/621a/d698071d0451d193f3a016134eecf278aa6b.pdf (Accessed 16.6.2019)

Tkach, R., Musich, S., MacLeod, S., Kraemer, S., Hawkins, K., Wicker, E. R. \& Armstrong, D. G. (2017). A qualitative study to examine older adults' perceptions of health: Keys to aging successfully. Geriatric Nursing, 38, 485-490, https://doi.org/10.1016/j.gerinurse.2017.02.009

Tovel, H., \& Carmel, S. (2014). Maintaining Successful Aging: The Role of Coping Patterns and Resources. J Happiness Stud, 15, 255-270, http://doi.org/10.1007/s $10902-013-9420-4$

Tuomi, K., Ilmarinen, J., Jahkola, A., Katajarinne, L., \& Tulkki, A. (1998). Work Ability Index, 2nd revised edition. Helsinki: Finnish Institute of Occupational Health. Retrieved from http://fr.scribd.com/doc/52853348/ Work-Abilty-Indeks-Book-Moch-Ahlan-Munajat-Fakultas-Teknik-dan-Ilmu-Komputer-Teknik-Industri-Universitas-Komputer-Indonesia (Accessed 16.6.2019).

Tuomi, K., Ilmarinen, J., Jahkola, A., Katajarinne, L., \& Tulkki, A. (2005). Indeks delovne zmožnosti [Capacity index]. Ljubljana: Inštitit Republike Slovenije za rehabilitacijo. von Bonsdorff, M., von Bonsdorff, M., Zhou, Z. E., Kauppinen, M., Miettinen, M., Rantanen, T., \& Vanhala, S. (2014). Organizational Justice, Selection, Optimization With Compensation, and Nurses' Work Ability. Journal of Occupational and Environmental Medicine, 326330, http://doi.org/10.1097/JOM.0000000000000102 WAI-Netzwerk Deutschland. (2015a). WAI-Fra- gebogen \& Auswertung (Kurzversion). Retrieved from http://wai-netzwerk.uni-wuppertal.de/ picture/upload/file/WAI-Kurzversion_mit $\% 20$ Auswertung_2015.pdf (Accessed 18.2.2018). WAI-Netzwerk Deutschland. (2015b). WAI-Fragebogen (Berechnungsmethode). Retrived from http://wai-netzwerk.uni-wuppertal.de/picture/upload/file/WAI-Berechnungsmethode_2015.pdf (Accessed 18.2.2018).

Weber, J., Jörres, R., Kronseder, A., Müller, A., Weigl, M. \& Chmelar, C. (2019). Learning on the job, the use of selection, optimization, and compensation strategies, and their association with telomere length as an indicator of biological aging. Int Arch Occup Environ Health, 92: 361. https://doi.org/10.1007/s00420-019-01408-5

Weigl, M., Müller, A., Hornung, S., Zacher, H., \& Angerer, P. (2013). The moderating effects of job control and selection, optimization, and compensation strategies on the age-work ability relationship. Journal of Organizational Behavior, 34(5), 607-628, http://doi.org/10.1002/job.1810

WHO. (2017). Retrieved from http://www.euro. who.int/en/health-topics/Health-systems/ nursing-and-midwifery (Accessed 13.8.2017)

Tuomi, K., Ilmarinen, J., Jahkola, A., Katajarinne, L., \& Tulkki, A. (2005). Indeks delovne zmožnosti [Capacity index]. Ljubljana: Inštitit Republike Slovenije za rehabilitacijo. von Bonsdorff, M., von Bonsdorff, M., Zhou, Z. E., Kauppinen, M., Miettinen, M., Rantanen, T., \& Vanhala, S. (2014). Organizational Justice, Selection, Optimization With Compensation, and Nurses' Work Ability. Journal of Occupational and Environmental Medicine, 326330, http://doi.org/10.1097/JOM.0000000000000102

WAI-Netzwerk Deutschland. (2015a). WAI-Fragebogen \& Auswertung (Kurzversion). Retrieved from http://wai-netzwerk.uni-wuppertal.de/picture/upload/file/WAI-Kurzversion mit $\% 20$ Auswertung 2015.pdf (Accessed 18.2.2018). WAI-Netzwerk Deutschland. (2015b). WAI-Fragebogen (Berechnungsmethode). Retrived from http://wai-netzwerk. uni-wuppertal.de/picture/upload/file/WAI-Berechnungsmethode 2015.pdf (Accessed 18.2.2018).

Weber, J., Jörres, R., Kronseder, A., Müller, A., Weigl, M. \& Chmelar, C. (2019). Learning on the job, the use of selection, optimization, and compensation strategies, and their association with telomere length as an indicator of biological aging. Int Arch Occup Environ Health, 92: 361. https://doi.org/10.1007/s00420-019-01408-5

Weigl, M., Müller, A., Hornung, S., Zacher, H., \& Angerer, P. (2013). The moderating effects of job control and selection, optimization, and compensation strategies on the age-work ability relationship. Journal of Organizational Behavior, 34(5), 607- 628, http://doi.org/10.1002/job.1810

WHO. (2017). Retrieved from http://www.euro. who.int/en/health-topics/Health-systems/nursing-and-midwifery (Accessed

13.8.2017) 
Tanja Žmauc holds a bachelor's degree in Nursing care and postgraduate 2nd degree in Management $\mathrm{He}$ alth and Social Organization of Faculty of Health Sciences and Faculty of Organizational Sciences, University of Maribor. Currently she's concluding her PhD thesis in Social Gerontology at Alma Mater Europaea (ECM). Her research focuses on nurses aged fifty years and more. She has over 25 years of professional experience as a nurse in several different fields and levels of work at three hospitals in Slovenia.

Danica Železnik PhD is a full-time professor at the Faculty of Health and Social Sciences in Slovenj Gradec. Her research is focused on the field of health sciences and gerontology. She is the author and co-author of numerous scientific articles. She also published a scientific monograph and three textbooks for higher education students. She is a member of the Komisija za medicinsko etiko Republike Slovenije, the Slovenian national ethics committee.

Oto Težak PhD, currently employed at Faculty of Electrical Engineering and Computer Science, University of Maribor as a researcher. His main interest is at field of cybernetics, process control, intelligent systems, modelling and measurement. His bibliography includes 169 items, of which more than 70 are scientific contributions. 


\section{Appendix}

\section{Work Ability Index (WAI) questionnaire short version}

\section{Q1 Current work ability compared to the best work ability}

Assume that your work ability at its best has a value of 10 points. How many points would you give your current work ability? (0 means that you cannot currently work at all)

\section{Q2 Work ability in relation to demands for work}

"How do you rate your current work ability with respect to the physical demands of your work?"

- $\quad$ very good (5 points)

- $\quad$ rather good (4 points)

- $\quad$ moderate (3 points)

- $\quad$ rather poor (2 points)

- $\quad$ very poor (1 point)

"How do you rate your current work ability with respect to the mental demands of your work?"

- $\quad$ very good (5 points)

- $\quad$ rather good (4 points)

- moderate (3 points)

- $\quad$ rather poor (2 points)

- $\quad$ very poor (1 point)

Q3 Diagnosed diseases (only diseases diagnosed by a physician are counted).

List of 14 disease groups:

- Injury from accidents

- Musculoskeletal diseases

- Cardiovascular diseases

- Respiratory disease

- Mental disorder

- Neurological and sensory disease

- Digestive disease

- Genitourinary disease

- $\quad$ Skin diseases

- Tumour

- Endocrine and metabolic diseases

- Blood diseases

- Birth defects

- $\quad$ Other disorder or disease (what?)

Q4 Estimated work impairment due do diseases

- Is your illness or injury a hindrance to your current job?

- There is no hindrance/l have no diseases (6 points)

- I I am able to do my job, but it causes some symptoms (5 points)

- I must sometimes slow down my work pace or change my work methods (4 points)

- I must often slow down my work pace or change my work methods (3 points)

- $\quad$ Because of my disease, I feel I am able to do only part-time work (2 points)

- In my opinion, I am entirely unable to work (1 point)

Q5 Sick leave during the past year (12 months)

- $\quad$ none at all (5 points)

- $\quad$ at the most 9 days (4 points)

- $10-24$ days (3 points)

- $\quad 25-99$ days (2 points)

- $\quad 100-356$ days (1 point) 


\section{Q6 Own prognosis of work ability two years from now}

"Do you believe that - from the standpoint of your health - you will be able to do your current job two years from now?"

- $\quad$ unlikely (1 point)

- $\quad$ no certain (4 points)

- relatively certain (7 points)

\section{Q7 Mental resources}

"Have you recently been able to enjoy your regular daily activities?"

- often (4 points)

- $\quad$ rather often (3 points)

- $\quad$ sometimes (2 points)

- $\quad$ rather seldom (1 point)

- $\quad$ never (0 points)

"Have you recently been active and alert?"

- $\quad$ often (4 points)

- $\quad$ rather often (3 points)

- $\quad$ sometimes (2 points)

- $\quad$ rather seldom (1 point)

- $\quad$ never (0 points)

"Have you recently felt yourself to be full of hope for the future?"

- continuously (4 points)

- $\quad$ rather often (3 points)

- $\quad$ sometimes (2 points)

- $\quad$ rather seldom (1 point)

- $\quad$ never (0 points) 